\title{
Sacrificial Thermally Sprayed Aluminium Coatings for Marine Environments: A Review
}

\author{
Berenika Syrek-Gerstenkorn ${ }^{1,2}$, Shiladitya Paul ${ }^{3,4, *(\mathbb{D}}$ and Alison J Davenport ${ }^{1}$ \\ 1 School of Metallurgy and Materials, University of Birmingham, Edgbaston, Birmingham B15 2TT, UK; \\ BAS684@student.bham.ac.uk (B.S.-G.); a.davenport@bham.ac.uk (A.J.D.) \\ 2 National Structural Integrity Research Centre, Cambridge CB21 6AL, UK \\ 3 TWI, Cambridge CB21 6AL, UK \\ 4 School of Engineering, University of Leicester, University Road, Leicester LE1 7RH, UK \\ * Correspondence: Shiladitya.Paul@twi.co.uk
}

Received: 16 January 2020; Accepted: 4 March 2020; Published: 12 March 2020

\begin{abstract}
One of the corrosion mitigation methods that is used for the protection of steel operating in seawater environments involves the application of sacrificial metallic coatings (such as aluminium, zinc, and their alloys). This paper reviews current knowledge about thermally-sprayed (TS) and cold-sprayed (CS) Al coatings for the corrosion protection of steel. It also summarises the key findings of the substantial amount of work that has been devoted to understanding mechanisms and the parameters that control the performance of TS Al coatings, such as the spraying method and its parameters like coating thickness and the application of sealer. The paper includes suggestions for areas of further research that could lead to the development of more resilient and longer-lasting coatings, based on the results from both laboratory and field tests that have been published in the literature. It also highlights the need for conducting simulated laboratory tests at conditions of intended service and the importance of long-term testing.
\end{abstract}

Keywords: thermally-sprayed aluminium (TSA); anti-corrosion coatings; cold spray; cathodic protection; seawater; corrosion

\section{Introduction}

The corrosion protection of structures that operate in seawater environments is a particularly important issue. It has been estimated that the cost of corrosion is high, not only in terms of financial loss (3.4\% of global GDP in accordance to the NACE report [1], but widely believed to be between 3\% and $4 \%$ ) but also in the number of lives lost due to catastrophic failures and environmental damage (when toxic products leak out from corroded equipment). The battle against corrosion can be supported in several ways: by appropriate material selection (e.g., corrosion-resistant alloys (CRAs)), by the application of coatings (organic or metallic), by cathodic protection (impressed current or sacrificial anodes), or by the use of corrosion inhibitors and corrosion allowance. The most common corrosion mitigation methods for the protection of offshore structures that are made of steel (usually mild or low-alloyed [2]) involve the application of cathodic protection and/or protective coatings, depending on the conditions to which the structure is subjected. The types of exposure for these materials can be divided into four main zones: atmospheric, splash/tidal, submerged, and buried. Parts of an offshore structure that are constantly immersed in seawater are usually protected by the application of cathodic protection, while parts that are exposed to the marine atmosphere are usually protected by protective coatings. In the splash/tidal zone however, the corrosion of steel is usually controlled by robust coatings and corrosion allowance (in the splash zone) as well as cathodic protection (for parts located below mean water level) [3]. This is the most severe and the most challenging area for corrosion protection 
due to alternating wetting and drying conditions, easy access to oxygen, atmospheric pollutants, UV radiation, and erosive actions combined with frequent contact with floating objects such as debris, boats or ice.

Protective coatings can be divided into: inorganic (for example ceramic (e.g., alumina) or carbon coatings), organic (such as epoxy and polyurethane), organic-inorganic hybrids (also known as smart or functionalised coatings), and metallic coatings [4]. Depending on the electrode potential with respect to the substrate metal (usually steel), metallic coatings can be formed either anodic (e.g., aluminium and zinc) or cathodic (e.g., nickel and copper). The primary function of protective coatings is their barrier properties. However, if the integrity of the coating is compromised and the substrate is exposed, the corrosion of either the substrate (in case of organic and cathodic coatings) or the coating (in case of sacrificial anodic coatings) will develop [5].

The aim of this paper was to review and summarise current knowledge about thermally-sprayed aluminium (TSA) coatings (formed by electric arc or wire flame) for the corrosion protection of steel operating in seawater environments and to suggest potential areas for further research. Sacrificial protection mechanisms that are provided by those coatings and the effect of various parameters (such as coating thickness and composition, spraying parameters, application of sealants and operating conditions) are discussed. A comparison with cold-sprayed aluminium coatings is also presented. Laboratory tests and in-service performance of the coatings are discussed and summarised.

\section{Sacrificial Coatings}

Metallic coatings (which are more active than steel) such as Al, Zn, and their alloys (Figure 1), supply cathodic protection to the substrate by working as a sacrificial anode. When $\mathrm{Al}$ (or $\mathrm{Zn}$ ) and steel are coupled together and exposed to seawater, a galvanic couple is established between those two metals, and electrons flow from the coating (anode) towards the substrate (cathode), which is accompanied by the dissolution of the coating, as schematically shown in Figure 2. When steel is cathodically protected, calcareous matters deposit on its surface (due to local $\mathrm{pH}$ changes explained in Section 4.5), which decrease the cathodic protection (CP) demand.

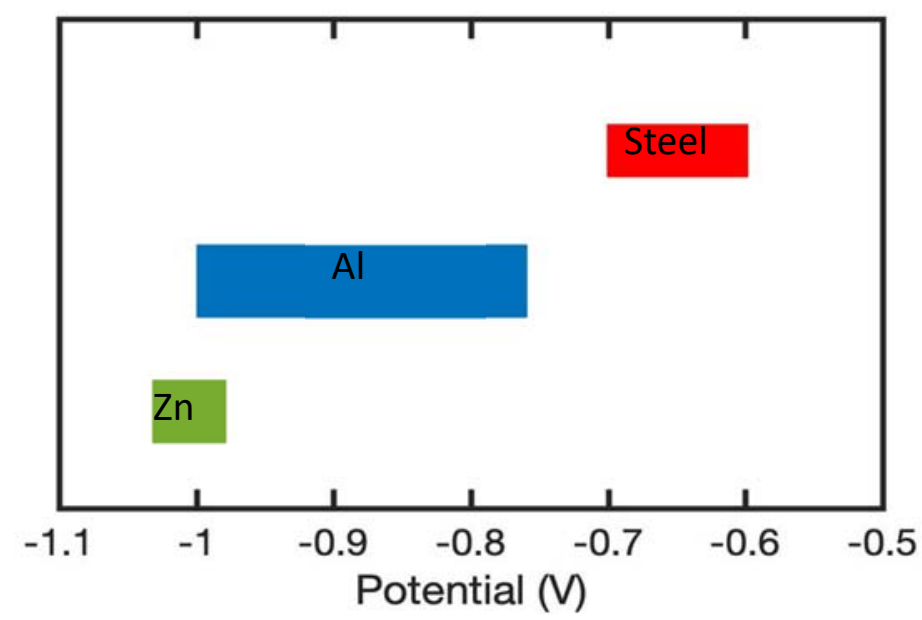

Figure 1. Galvanic series in seawater showing corrosion potential of steel, $\mathrm{Al}, \mathrm{Zn}$ and their alloys. All values are against saturated calomel electrode (SCE). 


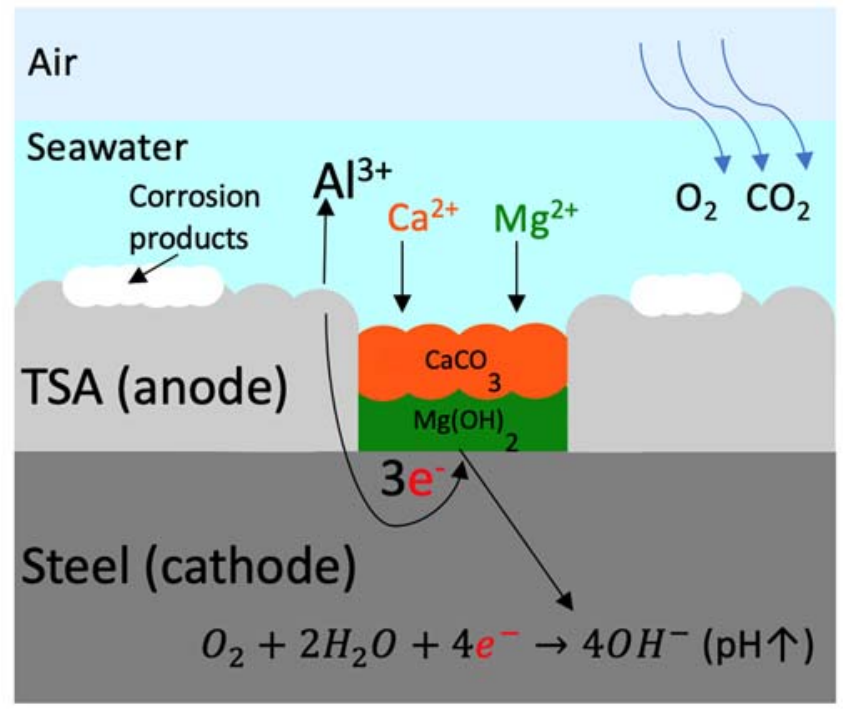

Figure 2. Sacrificial protection mechanisms provided by Al coatings

There are two key factors that determine the performance of sacrificial coatings:

- $\quad$ Low self-corrosion rate.

- Current output enabling the polarisation of the steel in the protective regime, usually considered to be between -0.8 and $-1.1 \mathrm{~V}(\mathrm{Ag} / \mathrm{AgCl} /$ seawater) [6]. Values more negative than $-1.1 \mathrm{~V}$ are generally not recommended to avoid excessive hydrogen generation.

There are many advantages of sacrificial metallic coatings:

- $\quad$ Barrier properties combined with cathodic protection.

- $\quad$ Newly applied coatings can be handled immediately (i.e., no drying time) [7].

- $\quad$ Spraying and repair can be performed on-site.

- $\quad$ More economical over the lifetime than organic coatings (total life cycle cost).

- $\quad$ Good resistance to mechanical damage.

\section{Thermal Spraying}

Though there are several thermal spray processes that can be used for the preparation of coatings, only two of them are commonly used for the deposition of sacrificial metallic coatings, namely electric arc and flame spray. Both involve propelling molten or semi-molten metal particles towards the substrate by a stream of air, thus creating a layer-by-layer deposition, until the required thickness of the coating is achieved. In contrast to other techniques, the two spraying processes above can be performed on-site and are economical.

A less commonly used technique for the deposition of metallic coatings is cold spray. This process, even though it is the costliest, has some advantages over the aforementioned techniques. Cold spray relies on the deposition of metallic powders in the solid-state, which means that no heat source such as flame or arc is needed, which can be critical when spraying materials that are highly sensitive to oxidation. The process can be performed in an area with a high risk of catching fire (e.g., an oil rig). There is no UV radiation during cold spraying, so no special eye protection measures are needed. Moreover, coatings that are prepared by cold spray tend to have a lower level of porosity [8], as can be seen in Figure 3. 


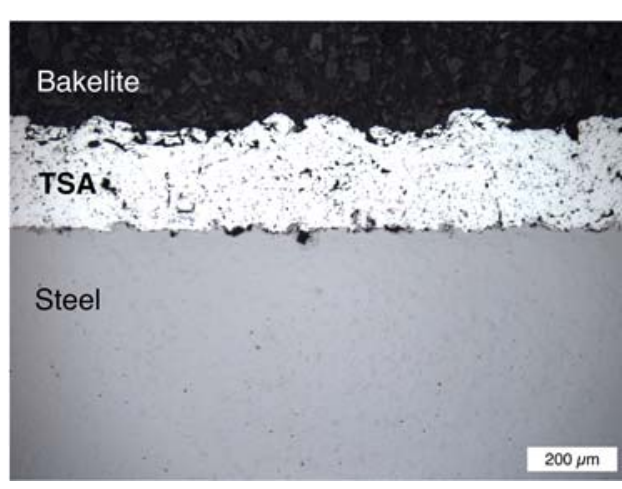

(a)

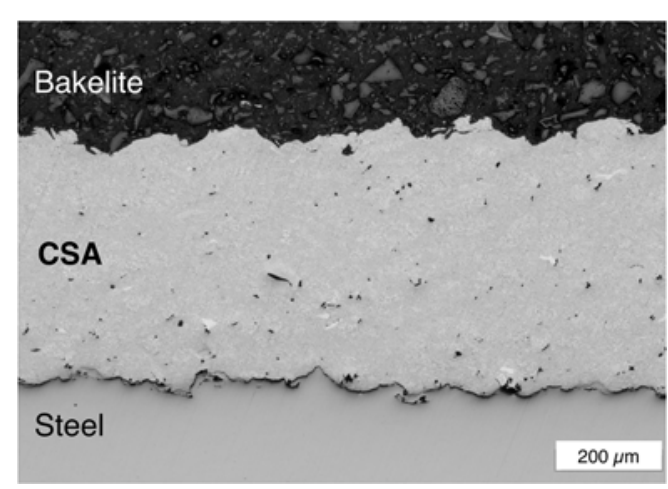

(b)

Figure 3. Cross-section of arc-sprayed $\mathrm{Al}$ coating (a) and cold-sprayed $\mathrm{Al}-12 \% \mathrm{Si}$ coating (b) on steel.

\subsection{Electric Arc Spraying}

This technique, also known as twin wire arc or wire arc spray, is based on melting the tips of two metallic wires with an electric arc, which is established between them through the application of direct current (DC). Molten particles are then accelerated and propelled towards the substrate via an air stream. More information about the process can be found elsewhere: [9-11].

\subsection{Wire Flame Spraying}

In this technique, a metallic wire is melted by a flame, and the molten particles are accelerated towards the workpiece by pressurised air. More details can be found elsewhere: [12,13].

\subsection{Cold Spraying}

In contrast to thermal spraying processes, cold spray relies on the deposition of particles in the solid state, and these particles plastically deform upon impact [14]. Since the melting of the feedstock material is avoided, a coating with a negligible oxide content can be obtained. Moreover, cold-spray coatings tend to be denser (achievable porosity level below 1\% [15]) than the coatings that are deposited by using low-velocity thermal spray processes, such as electric arc and wire flame spraying (typical porosity level between 5\%-15\% [16]), due to the lack of the splashing of molten droplets and the peening effect of solid particles, which close voids in the underlaying layer upon impact. Furthermore, since there is no melting of the feedstock material, the build-up of unfavourable tensile residual stresses arising from the thermal contraction of splats upon cooling is also reduced. This, combined with the peening effect, allows for the deposition of thicker coatings than the ones that are prepared by using arc or wire flame spraying [16]. A solid-state deposition also eliminates problems with the preferential evaporation of elements from feedstock material during spraying and maintains an unchanged phase composition of the coating as compared with the initial powder [16]. However, due to the low spray plume (typically $<1 \mathrm{~cm}$ in diameter), the coating of large surface areas can be time-consuming. A detailed description of the process can be found elsewhere [17].

\section{Laboratory Tests}

Corrosion protection that is provided by thermally-sprayed aluminium coatings has been a subject of many investigations during the past three decades. Attempts have been made to understand the mechanisms and parameters that influence the performance of the coatings by using different methods. The most notable findings are reviewed below.

\subsection{Effect of the Spraying Method and Its Parameters}

A comparison between TSA coatings that are deposited by using electric arc (EA) and flame spraying (FS) was conducted by several researchers. Rodriguez et al. [18] observed differences in 
the oxide layers of coatings that were deposited by using arc and flame spraying through the use X-ray photoelectron spectroscopy (XPS). They also detected the different corrosion products that were formed on those coatings after a 4000-hour saline mist test: bayerite in the FS process and boehmite in the coating that was deposited by EA. Gartland and Eggen [19] concluded, based on their lab and field tests on TSA that was prepared by using both methods, that the spraying method had little influence on the performance of the coating, but the arc-sprayed coatings exhibited better adhesion (arc-sprayed Al: $9.0 \pm 1 \mathrm{MPa}$, flame-sprayed Al: $3.5 \pm 0.34 \mathrm{MPa}$ ). A higher adhesion of arc-sprayed coatings was also reported by others [20,21]. Moreover, coatings that are prepared by flame spraying tend to exhibit a higher level of porosity in comparison to the ones that are prepared by arc-spraying [9]. Porosity is an inevitable characteristic feature of thermally-sprayed coatings, but its level can be altered by selecting appropriate feedstock material, application method, and spraying parameters. To obtain a less porous coating, oxyfuel flame spraying and small diameter wire (1.6 and $2.3 \mathrm{~mm}$ ), or low current (100-200 A) arc spraying should be used [22]. It has also been estimated that arc-spraying is more economical [9].

For cold-sprayed $\mathrm{Al}$ coatings, it has been recognised that a finer powder size provides better corrosion protection to the underlying steel due to its lower porosity level. Coatings that were prepared with $40-50 \mu \mathrm{m}$ and $50-75 \mu \mathrm{m} \mathrm{Al}$ powders performed well, both under $\mathrm{NaCl}$ immersion and 11 years of atmospheric exposure [23]. A better performance of cold-sprayed Al coatings (attributed to their lower porosity level) than arc-sprayed coatings in natural seawater was observed by other researchers [8].

\subsection{Effect of Coating Thickness}

The effect of TSA coating thickness on corrosion performance was studied by Han et al. [24] by using electrochemical methods. They used stainless steel STS 304 steel substrates. Several experiments were performed, and their data were presented in the paper. However, based on the presented results, meaningful conclusions could not be drawn.

The results of the mechanical testing of arc-sprayed Al coatings $(222-397 \mu \mathrm{m})$ on mild steel showed that the adhesion strength of the coatings increased with the coating thickness [25]. However, even the $222 \mu \mathrm{m}$ coating showed a very good adhesion strength of $10.74 \mathrm{MPa}$. The minimal required adhesion strength of TS aluminium coatings varies across different standards from 4.5 to $10.3 \mathrm{MPa}$, as shown in Table 1.

Table 1. Adhesion strength specifications for thermally-sprayed aluminium coatings in key standards.

\begin{tabular}{cc}
\hline Standard & Min. Adhesion Strength [MPa] \\
\hline ISO 2063 & 4.5 \\
SSPC-CS 23.00/AWS C2.23M/NACE No. 12 & 6.89 \\
NORSOK M-501 & 9 \\
AWS C2.18-93 & 10.3 \\
\hline
\end{tabular}

However, laboratory tests that were performed by Thomason et al. [26] on flame-sprayed Al coatings revealed that a high coating thickness $(\sim 400-450 \mu \mathrm{m})$ may lead to the development of blisters, especially in an aggressive splash zone environment. It was suggested that residual stresses are higher in thick coatings. A similar correlation between the coating thickness and the tendency to develop blisters was also reported in a 19-year study conducted by the American Welding Society [27].

In order to provide a sufficient level of protection for the whole service life of a structure, the coating must not be too thin. The corrosion rates of TSA in salt water environments that have been reported in the literature (Table 2)—although estimated by using different experimental methods, exposure periods and temperatures-suggest that the dissolution of the coating in seawater is probably less than $20 \mu \mathrm{m}$ year. This indicates a minimum coating thickness of $200 \mu \mathrm{m}$ for 10 years exposure. The AWS C.2 18-93 standard recommends thickness between 200 and $350 \mu \mathrm{m}$ for seawater immersion. 
Table 2. Corrosion rates of Al-coatings in simulated or natural seawater environments.

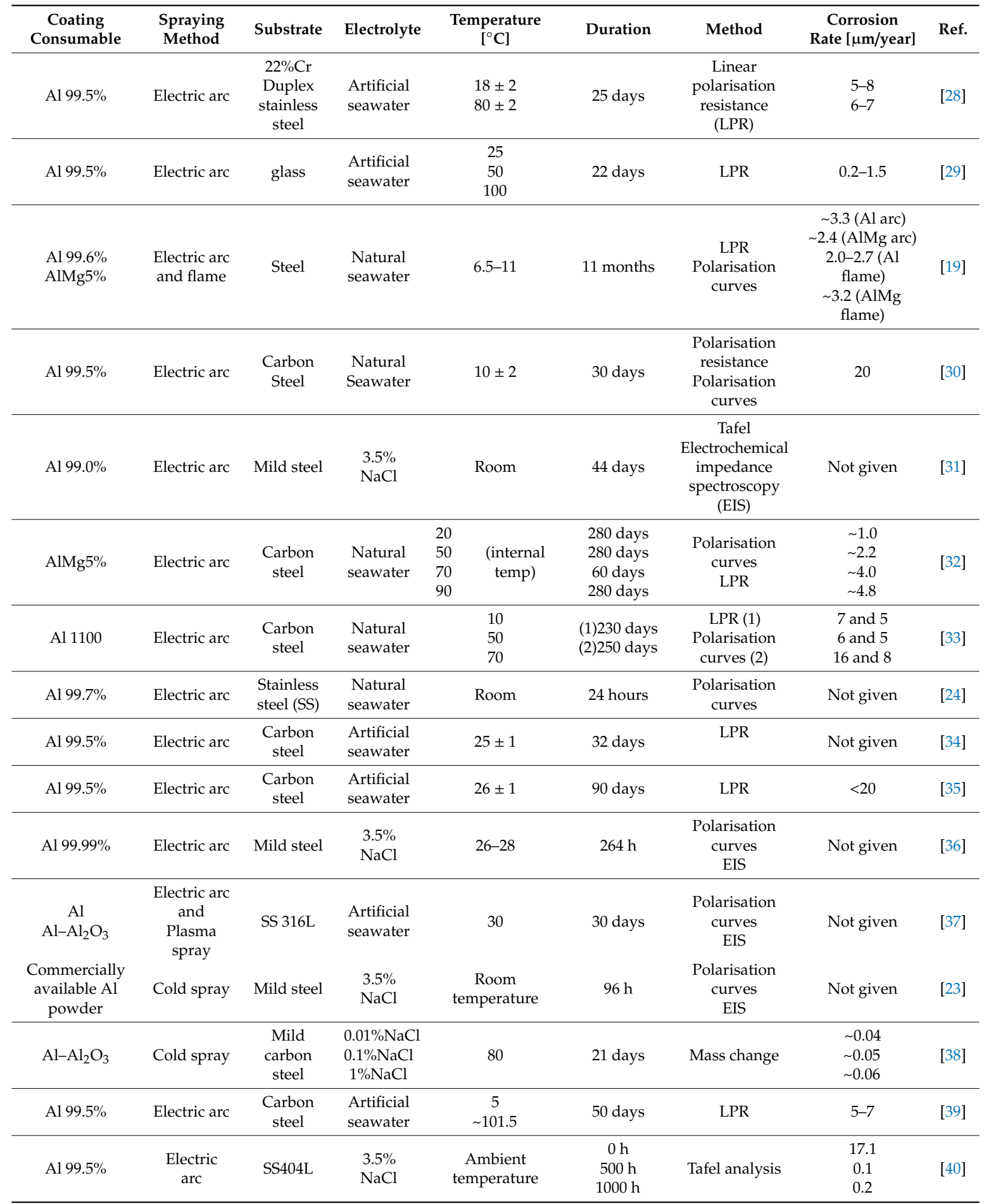




\subsection{Effect of Coating Composition}

The most commonly used alloys for the preparation of thermally-sprayed $\mathrm{Al}$ coatings for the corrosion protection of steel are $\mathrm{Al} 1050(99.5 \% \mathrm{Al})$ and $\mathrm{Al}-5 \% \mathrm{Mg}$, as can be seen from Table 2. ISO 2063-1 and NORSOK M-501 also recommend those alloys. The required compositions of relevant wires provided in AWS C2.25 and ISO 14919 are shown in Table 3.

Table 3. Composition of wire feedstock reported in relevant codes and standards.

\begin{tabular}{|c|c|c|c|c|c|c|c|c|c|c|c|c|}
\hline \multirow[b]{2}{*}{ Standard } & \multicolumn{12}{|c|}{ Element (wt\%) } \\
\hline & UNS & $\begin{array}{l}\text { Common } \\
\text { Name }\end{array}$ & Al & $\mathrm{Cr}$ & $\mathrm{Cu}$ & $\mathrm{Fe}$ & Mn & $\mathrm{Si}$ & $\mathrm{Ti}$ & $\mathrm{Zn}$ & $\mathrm{Mg}$ & Other \\
\hline \multirow{4}{*}{$\begin{array}{l}\text { AWS } \\
\text { C2.25 }\end{array}$} & A91100 & $\mathrm{Al}(1100)$ & $\begin{array}{c}99.00 \\
\text { min }\end{array}$ & - & $0.05-0.20$ & $\begin{array}{l}0.95(\mathrm{Fe} \\
\text { and } \mathrm{Si})\end{array}$ & 0.05 & $\begin{array}{l}0.95(\mathrm{Fe} \\
\text { and } \mathrm{Si})\end{array}$ & - & 0.10 & - & - \\
\hline & A91350 & $\mathrm{Al}(1350)$ & $\begin{array}{c}99.50 \\
\min \end{array}$ & 0.01 & 0.05 & 0.40 & 0.01 & 0.10 & $\begin{array}{c}0.02 \\
(\mathrm{~V}+\mathrm{Ti})\end{array}$ & - & & \multirow{3}{*}{$\begin{array}{c}\mathrm{GaB} \\
(0.03-0.05) \\
\\
\mathrm{Al}_{2} \mathrm{O}_{3} \\
(8-12)\end{array}$} \\
\hline & A95356 & $\mathrm{Al}-5 \mathrm{Mg}$ & Rem. & $0.05-0.20$ & 0.10 & 0.40 & $0.05-0.20$ & 0.25 & $0.06-0.20$ & 0.10 & $4.5-5.5$ & \\
\hline & A71001 & $\mathrm{Al} \mathrm{MMC}$ & $\begin{array}{l}88 \\
\text { min }\end{array}$ & - & - & - & - & - & - & - & & \\
\hline \multirow{2}{*}{$\begin{array}{c}\text { ISO } \\
14919\end{array}$} & \multirow{2}{*}{$\begin{array}{l}\text { Not } \\
\text { provided }\end{array}$} & Al 99.5 & $\begin{array}{l}99.5 \\
\min \end{array}$ & - & $\leq 0.02$ & $\leq 0.40$ & $\leq 0.02$ & $\leq 0.25$ & $\leq 0.02$ & $\leq 0.07$ & & $\leq 0.03$ \\
\hline & & $\mathrm{Al}-5 \mathrm{Mg}$ & Rem. & $0.05-0.2$ & $\leq 0.10$ & $\leq 0.40$ & $0.05-0.20$ & $\leq 0.30$ & $0.06-0.20$ & $\leq 0.10$ & $4.5-5.6$ & $\leq 0.15$ \\
\hline
\end{tabular}

Pure aluminium shows excellent corrosion resistance due to its passive nature. When exposed to an oxidising environment (e.g., air and water), a continuous and uniform natural oxide film $\left(\mathrm{Al}_{2} \mathrm{O}_{3}\right)$ develops on the metal's surface, which works as an electrical insulator. It prevents the movement of electrons (produced during the anodic dissolution of the metal) from the metal to the oxide/solution interface, which results in the inhibition of cathodic reactions.

$\mathrm{Mg}$, when added in small amounts, improves the mechanical properties of solid $\mathrm{Al}$, but it does not decrease its corrosion performance. However, alloys containing $3 \% \mathrm{Mg}$ or more are susceptible to the precipitation of intermetallic particles $\left(\mathrm{Al}_{3} \mathrm{Mg}_{2}\right)$ at the grain boundaries when exposed to elevated temperatures for a longer period of time [41]. Those particles are anodic in relation to the Al matrix and corrode preferentially, leading to intergranular corrosion and stress corrosion cracking [42]. In the case of thermally-sprayed Al, Morakul et al. [43], who tested $\mathrm{Al}-2 \% \mathrm{Mg}$ and $\mathrm{Al}-5 \% \mathrm{Mg}$ in $3.5 \%$ $\mathrm{NaCl}$ at $25{ }^{\circ} \mathrm{C}$, reported a lower corrosion resistance and a shorter fatigue life of the coating with a higher $\mathrm{Mg}$ concentration. At elevated temperatures, thermally-sprayed $\mathrm{Al}-5 \% \mathrm{Mg}$ coatings with and without external CP were tested by Wilson et al. [32], who observed coating degradation (thickness reduction) at higher temperatures. They suggested the possible degradation mechanism as being chemical dissolution. Moreover, one of the samples that was exposed to $90{ }^{\circ} \mathrm{C}$ (internal temperature of the pipe) exhibited blistering.

In 2017, Quale et al. [30] tested a thermally-sprayed sacrificial coating comprised of $\mathrm{Al}$, Zn and In, based on the assumption that the addition of $\mathrm{Zn}$ and In to aluminium prevents its passivation. The results of the tests revealed that the open circuit potential (OCP) of the freely corroding Al-Zn-In coating reached $-1000 \mathrm{mV}(\mathrm{Ag} / \mathrm{AgCl})$ after 60 days in natural seawater and was $65 \mathrm{mV}$ more negative than the $\mathrm{Al}(99.5 \%)$ coating. The difference was even more pronounced after 235 days when the coatings were coupled to carbon steel in a 10:1 ratio and the Al-Zn-In coating reached $-972 \mathrm{mV}$, whereas the $\mathrm{Al}$ coating stabilised at $-803 \mathrm{mV}$. It was concluded that the $\mathrm{Al}-\mathrm{Zn}-\mathrm{In}$ coating provides better protection than a conventional TSA coating due to its better CP efficiency. Moreover, the Al-Zn-In coating can be used in conjunction with conventional anodes with minimal current drain. It was also noticed that thermal spraying leads to a reduction of $\mathrm{Zn}$ content in the deposited coating.

In 2019, Adamiak et al. [44] tested arc-sprayed Al coatings with and without NiAl-buffered sub-coating on armour-grade steel. They observed that the use of the sub-coating increases adhesion and improves erosion wear resistance of the $\mathrm{Al}$ layer. 


\section{$\mathrm{Al} / \mathrm{Al}_{2} \mathrm{O}_{3}$ Composites}

Some attempts have been made to improve the corrosion and mechanical properties of $\mathrm{Al}$ cold-sprayed coatings by reinforcing $\mathrm{Al}$ with $\mathrm{Al}_{2} \mathrm{O}_{3}[38,45,46]$.

Based on the lab tests in a $3.5 \% \mathrm{NaCl}$ solution, it was noticed that even though the reinforced coating exhibited a higher corrosion resistance during a short immersion $(<200 \mathrm{~h})$, its corrosion performance significantly worsened during longer immersion due to the severe corrosion of the aluminium matrix [46].

Huang et al. [47] tested an $\mathrm{Al} / \mathrm{Al}_{2} \mathrm{O}_{3}$ flame-sprayed coating for marine applications. They observed a formation of an alumina skeleton inside the coatings, which gives rise to increased mechanical and barrier properties for the penetration of $\mathrm{Cl}^{-}$ions. Moreover, they reported the dissolution of $\mathrm{Al}$ splats which were not connected to the $\mathrm{Al}_{2} \mathrm{O}_{3}$ frame.

A better performance of the composite coating was also reported by Abdoli et al. [37] after a 30-day immersion in artificial seawater (ASTMD1141) (with and without the addition of Escherichia coli bacteria) for 30 days.

\subsection{Effect of Sealing}

As shown by Lee et al. [36], corrosion products that form on Al-coated steel enhance the barrier properties of the coating by blocking the pores and cracks inside the coating. However, during the initial immersion, when corrosion deposits are not present, the dissolution of the $\mathrm{Al}$ coating can be relatively high. Moreover, if the coated structure is stored in a humid environment before being placed in service, rust staining may occur [7].

To prolong the lifetime of TSA coatings and prevent the development of discoloured areas, suitable sealant systems can be applied. Sealants are designed to penetrate and fill the surface-connected porosity, suppressing the diffusion of corrosive molecules from the environment through the coating.

Organic sealants are comprised of epoxies, phenolics, furans, polymethacrylates, silicones, polyesters, polyurethanes, and polyvinyl esters. For TSA, aluminium-filled vinyl and silicone have been used [48]. In accordance with the NORSOK M-501 standard [49], for low-temperature operations (below $120^{\circ} \mathrm{C}$ ), two-component epoxy should be used, whereas for high-temperature applications (above $120^{\circ} \mathrm{C}$ ), aluminium silicone should be used. Information on organic materials that are compatible with TSA is provided in ISO 1244-5. ISO 2063 and AWS C2.23, mention that the thickness of sealants should not exceed $40 \mu \mathrm{m}$. López-Ortega et al. [2,50] conducted a series of experiments in which arc-sprayed aluminium with an organic topcoat (epoxydic paint [51]) on high strength, low alloy steel R4 grade was studied. Based on weathering aging tests in different climatic cabinets, as well as immersion tests and tribocorrosion tests in artificial seawater, it was concluded that this duplex system exhibits good corrosion and tribocorrosion properties. The same group [51] also studied a functionalised topcoat system containing $25 \%$ wt of $\mathrm{SiO}_{2}$ and a $1.5 \mathrm{wt} \% \mathrm{Cu}_{2} \mathrm{O}$ (to obtain superhydrophobicity and antibacterial characteristics) on a TSA coating that was modified by plasma electrolytic oxidation (PEO). The use of PEO on TSA was previously reported to be a promising technique for improved corrosion and wear resistance [52,53]. The effect of an epoxy sealant applied on an arc-sprayed $\mathrm{Al}$ coating by using a cathode electrophoresis method was investigated by Pang et al. [54] and compared with sealing by using boiling water. After immersion in $3.5 \% \mathrm{NaCl}$ at $40{ }^{\circ} \mathrm{C}$ for seven days, it was observed that the thickness of epoxy-sealed TSA was unchanged but the thickness of the TSA that was sealed by using boiling water decreased from 100 to $40 \mu \mathrm{m}$.

Other inorganic sealing methods that have been investigated to enhance the behaviour of thermally-sprayed coatings have involved the thermal diffusion of $\mathrm{Zn} \mathrm{[55],} \mathrm{the} \mathrm{use} \mathrm{of}$ phosphate-containing salts that chemically react with $\mathrm{Al}$ [56], calcium nitrate [57], hydrothermal treatment in boiling deionised (DI) water [58], and the sol-gel method [59]. The use of glass powders to seal porosity in an arc-sprayed aluminium coating was also investigated [60]. 
The reduced porosity level of an arc-sprayed aluminium coating was also achieved by Wenming et al., who used a $\mathrm{CO}_{2}$ laser to re-melt the coating [61]. They also noticed that the re-melting of the coating changed the way the coating adhered to the substrate from mechanical to metallurgical bonding.

Though the use of sealants can significantly improve the performance of TSA, it should be noted that there have been some examples where sealed coatings developed blisters (Hutton tension leg platform [62]) or failed prematurely (Heidrun platform [26]). The degradation mechanisms of painted TSA was studied first by Knudsen [63] and later by Sumon et al. [64]. Knudsen attributed the accelerated degradation of TSA to the development of an acidic environment underneath the paint. His work focused on the scenarios where TSA/organic system was either in electrical contact with bare steel or contained a defect. Sumon et al. tested several organic coatings on TSA (with and without a scribe) and bare steel by using salt spray exposure. They observed organic coating delamination on TSA-coated samples, not only on scribed samples but also on intact ones due to the diffusion of water and chloride ions through the epoxy layer. The proposed organic coating disbonding mechanisms included the development of voluminous corrosion products lifting the organic layer, anodic undermining, and cathodic disbonding.

\subsection{Effect of Damage}

As mentioned in previous sections, when an aluminium coating gets damaged and the steel is in direct contact with an electrolyte, a galvanic couple is established between the coating and the substrate due to the potential difference between those two metals. Since Al exhibits more active potential than steel in seawater, it undergoes dissolution accordance to Equation (1):

$$
A l \rightarrow A l^{3+}+3 e^{-}
$$

Electrons that are produced during the above reaction are consumed at the steel (cathode) according to the following reactions:

$$
\begin{aligned}
& \mathrm{O}_{2}+2 \mathrm{H}_{2} \mathrm{O}+4 e^{-} \rightarrow 4 \mathrm{OH}^{-}, \\
& 2 \mathrm{H}_{2} \mathrm{O}+2 e^{-} \rightarrow \mathrm{H}_{2}+2 \mathrm{OH}^{-},
\end{aligned}
$$

The production of $\mathrm{OH}^{-}$ions during cathodic reactions causes an increase in the $\mathrm{pH}$ of the solution in the vicinity of the cathode, which triggers the precipitation of calcareous matters. These deposits, depending on the temperature, provide higher or lower barrier properties to the underlying steel.

In a paper published by Thomason, it was suggested that a holiday (a discontinuity: defect, pinhole, crack etc.) in a coating as large as $50 \%$ could be successfully protected by a TSA coating for a few years and for 20 years in the case of a $6 \%$ holiday in a $200 \mu \mathrm{m}$ flame-sprayed coating [65].

Modelling work done by using the final element method (FEM) that was conducted by Huang et al. showed that a cold-sprayed AlZn coating can only provide protection to the substrate when the damage in the coating is not larger than $1 \mathrm{~mm}$ in width [66]. However, it should be pointed out that, in this study, the effects of calcareous deposits and corrosion product formations were not included.

\subsection{Effect of Temperature}

The behaviour of TSA (Al-5\%Mg) coatings (with and without $\mathrm{CP}$ ) in natural seawater at different temperatures was studied by Wilson et al. [32]. In their experiments, carbon steel pipes with TSA coatings were internally heated to $20,50,70$ and $90{ }^{\circ} \mathrm{C}$ and exposed to seawater $\left(8-10^{\circ} \mathrm{C}\right)$. It was observed that the corrosion rate increased with increasing temperature. Moreover, high initial corrosion rates that were recorded at all temperatures decreased with time below $10 \mu \mathrm{m} /$ year after approximately 40-50 days. Based on the analysis of the thickness loss of the coatings, it was suggested that TSA (in conjunction with $\mathrm{CP}$ ) might undergo chemical dissolution at elevated temperatures [32]. It was also noted that temperature influences the type and amount of calcareous deposits that were formed on the 
coatings. Deposits that were formed at higher temperatures contained a higher amount of $\mathrm{Mg}$, whereas at lower temperatures, the deposits mainly consisted of $\mathrm{CaCO}_{3}$. Experiments that were conducted by other researchers [67] on TSA (AA1050) that contained defects (4\%) in boiling synthetic seawater (ASTM 1141) for up to $5000 \mathrm{~h}$ also revealed the formation of brucite as well as $\beta$-alumina and mixed hydrated oxides of $\mathrm{Mg}$ and $\mathrm{Al}$. $\mathrm{No} \mathrm{CaCO}_{3}$ was detected in the holiday (defect) region.

The precipitation of calcareous deposits during the corrosion of TSA coatings with a $4 \%$ defect was also studied in synthetic seawater at 30 and $60^{\circ} \mathrm{C}$ by Ce and Paul [68]. The authors conducted $\mathrm{pH}$ measurements during the corrosion of samples that were exposed to seawater for up to $350 \mathrm{~h}$ and observed that the local $\mathrm{pH}$ of the TSA coating increased with time at $60{ }^{\circ} \mathrm{C}$ (to the value between 7 and 8.5), whereas the opposite behaviour occurred at $30^{\circ} \mathrm{C}$ (decreased to $\mathrm{pH} 4.76$ ). A higher $\mathrm{pH}$ was linked to the passivation phenomena. Moreover, different types of products were detected at those temperatures: $\mathrm{Al}(\mathrm{OH})_{3}$ at $30^{\circ} \mathrm{C}$ and $\mathrm{k}-\mathrm{Al}_{2} \mathrm{O}_{3}$ at $60^{\circ} \mathrm{C}$. Some Fe-containing corrosion products were observed on the sample exposed at $30^{\circ} \mathrm{C}$, and both aragonite and brucite were detected at both temperatures in the holiday region.

The effect of temperature on the precipitation of calcareous scales on cathodically protected steel was studied by Lin and Dexter [69]. They noticed that less calcareous deposits formed at temperatures $<\sim 10{ }^{\circ} \mathrm{C}$ and that at lower temperatures, the predominant phase was calcite $\left(\mathrm{CaCO}_{3}\right)$, whereas at higher temperatures, aragonite $\left(\mathrm{CaCO}_{3}\right)$ dominated. The difference was attributed to the inhibitive properties of $\mathrm{Mg}$ ions, which inhibit both nucleation and growth of calcite but only the nucleation of aragonite. Studies performed by Yang et al. [70] on cathodically protected steel in artificial seawater at $20{ }^{\circ} \mathrm{C}$ revealed the presence of double-layered deposits consisting of an Mg-rich inner layer and a calcium-rich outer layer. The development of calcareous layers on exposed steel is important in the context of the cathodic protection that is provided by TSA coatings because the deposits impede oxygen diffusion to the steel surface and reduce the rate of dissolution of aluminium.

The performance of cathodically polarised $(-1,-1.1$ and $-1.2 \mathrm{~V} \mathrm{Ag} / \mathrm{AgCl}) \mathrm{TSA}$ coatings that were exposed to seawater and mud at elevated temperatures was studied by Knudsen et al. [33,71]. They observed an increase in the corrosion rate of TSA with temperature. They also pointed out that the excessive polarisation to $-1.2 \mathrm{~V}$ of TSA that was exposed to mud led to the very rapid dissolution of the coating.

Significantly less attention has been given to the performance of TSA coatings at lower temperatures. However, two papers have been published by Paul on the performance on TSA coatings (with defects) at $5{ }^{\circ} \mathrm{C}$, the first one at ambient pressure [39] and the second one [72] under high pressure (50 MPa) to simulate deep sea conditions. Both tests revealed the formation of calcareous deposits in the holiday region, which consisted of a thin layer of $\mathrm{Mg}(\mathrm{OH})_{2}$ and a thick layer of $\mathrm{CaCO}_{3}$. In both cases, TSA provided full protection to the underlying steel.

Tests that were performed by Dexter [73] on aluminium metal in seawater revealed an ennoblement of the potential with temperature decrease. A similar trend should be expected for sprayed aluminium. If the potential of a coating is less negative at lower temperatures, its ability to provide cathodic protection (when coating gets damaged) is probably lower too. No papers focusing on the performance of TSA operating at temperatures below $5^{\circ} \mathrm{C}$ have been found in the literature.

\subsection{Effect of Oxygen}

Eighteen-day lab-based experiments [74] that were conducted in aerated and deaerated artificial seawater at $25{ }^{\circ} \mathrm{C}$ on TSA with $3 \%$ holiday showed that under deaerated conditions, the corrosion rate of TSA coatings is lower and calcareous deposits that are formed consist mainly of brucite $\left(\mathrm{Mg}(\mathrm{OH})_{2}\right)$.

The effect of oxygen on the galvanic corrosion of aluminium-steel couple in an $\mathrm{NaCl}$ solution was studied by Pryor and Keir [75]. They noticed that at $\mathrm{pH}$ lower than 4 and higher than 10, the galvanic current flow and mass change of Al were independent on the dissolved oxygen concentration, which was attributed to the main cathodic reaction being the reduction of water leading to the evolution of the hydrogen gas. Within the 4-10 $\mathrm{pH}$ range, however, dissolved oxygen had a strong effect on 
the galvanic corrosion. The saturation of the solution with oxygen resulted in an increase in galvanic current, whereas deaeration caused a decrease of the current to nearly zero.

\subsection{Effect of the Solution Chemistry}

It is well known that aluminium owes its good corrosion resistance in neutral aqueous environments to its passivating nature. Aluminium oxide, which is formed naturally on the surface of the bare metal, works as an electrical insulator. It inhibits the movement of electrons between the metal and the electrolyte, which results in the inhibition of cathodic reactions. However, for effective galvanic protection, $\mathrm{Al}$ needs to be able to corrode at a certain rate to successfully protect the steel substrate. It has been well documented in the literature that chloride ions are capable of breaking down the protective oxide layer, which leads to a localized form of corrosion [76-78]. Even though one would usually try to avoid any form of corrosion, in the case of sacrificial coatings, the presence of chloride ions can be beneficial. It has been observed that for atmospheric exposures, there is a critical threshold value of $100 \mathrm{mg} \mathrm{Cl}^{-} \mathrm{m}^{-2}$ day $^{-1}$, below which Al and Al-based coatings are ineffective [79]. Similar behaviour has also been observed under full immersion laboratory tests that were performed in $0.6 \mathrm{M} \mathrm{NaCl}$ and $0.6 \mathrm{M} \mathrm{Na}_{2} \mathrm{SO}_{4}$ [80]. The presence of $\mathrm{Cl}^{-}$ions was necessary for effective sacrificial performance, but no recommendations regarding minimum concentration were given.

The effect of magnesium and calcium ions on the performance on TSA coatings containing defects was recently studied by Echaniz et al. [35]. The 90-day immersion tests that were performed in different solutions revealed differences between calcareous deposits that were formed on the exposed steel. When samples were exposed to solutions that contained either magnesium or calcium ions, a single layer of either brucite or calcite, respectively, was formed. However, when both ions were present in the solution, a bi-layer consisting of aragonite on top of brucite was detected. Moreover, electrochemical measurements revealed more noble potential of the sample that was exposed to artificial seawater than to the solutions containing only a combination of the following salts: $\mathrm{MgCl}_{2}, \mathrm{CaCl}_{2}$, and $\mathrm{NaHCO}_{3}$.The reason for this could be due to the presence of $\mathrm{SO}^{2-}$ ions in artificial seawater. Those ions were detected in $\mathrm{Al}$ corrosion products by Syrek-Gerstenkorn et al. on TSA coatings after immersion in artificial seawater for 32 days [34]. Other researchers who studied the effect of $\mathrm{SO}^{2-}$ on the corrosion of aluminium in $\mathrm{NaCl}$ solution observed that the addition of those ions inhibited the initiation of pitting corrosion, but it enhances the growth of pre-existing pits [81]. The inhibitive effect of $\mathrm{SO}_{4}^{2-}$ was also reported by others [82].

\section{Long-Term Field Studies}

TSA coatings have proven to be an effective corrosion mitigation control for steel during several long-term field studies that were performed in the past three decades. The most notable ones are summarised in the Table 4 below. 
Table 4. Long-term field studies involving testing of thermally-sprayed aluminium (TSA) coatings.

\begin{tabular}{|c|c|c|c|c|c|c|c|c|c|}
\hline $\begin{array}{c}\text { Name/ } \\
\text { Organisation }\end{array}$ & $\begin{array}{l}\text { Exposure } \\
\text { Time }\end{array}$ & Exposure Type & Coating Material & Coating Thickness & Spraying Method & Sealed & $\begin{array}{c}\text { Holiday/ } \\
\text { Artificial } \\
\text { Defect }\end{array}$ & Findings & Ref. \\
\hline BISRA & 12 years & $\begin{array}{l}\text { Atmospheric (rural, } \\
\text { coastal industrial) } \\
\text { Seawater } \\
\text { immersion }\end{array}$ & $\mathrm{Zn}, \mathrm{Al}, \mathrm{Cd}, \mathrm{Pb}, \mathrm{Sb}$ & 3-4 mils & $\begin{array}{c}\text { Thermal } \\
\text { Spraying (type not } \\
\text { specified), } \\
\text { electroplating, and } \\
\text { hot dipping. }\end{array}$ & No & No & $\begin{array}{l}\text { Life of the coating roughly proportional to } \\
\text { the coating thickness regardless of the } \\
\text { application process. }\end{array}$ & {$[83,84]$} \\
\hline LaQue Centre & $\begin{array}{l}12 \text { years } \\
\text { extended to } 34 \\
\text { years }\end{array}$ & $\begin{array}{l}\text { Atmospheric } \\
\text { (marine and } \\
\text { industrial) }\end{array}$ & $\begin{array}{c}\text { Powders of various } \\
\text { compositions of } \mathrm{Zn}, \mathrm{Al}, \\
\mathrm{Zn} \text { and } \mathrm{Al} \\
\mathrm{Zn} \text { and } \mathrm{Al} \text { and } \mathrm{Mg} \\
\mathrm{Mn}, \\
\mathrm{Al} \text { and } \mathrm{Mg}\end{array}$ & $0.08-0.2 \mathrm{~mm}$ & $\begin{array}{l}\text { Powder flame } \\
\text { spraying }\end{array}$ & No & No & $\begin{array}{l}\text { Al-based coatings performed better than } \\
\text { Zn-based ones in industrial atmospheres } \\
\text { but worse in marine atmospheres after } 12 \\
\text { years exposure. } \\
\text { There were more resistant coatings with } \\
\text { high Al content than } \mathrm{Zn} \text { after longer ( } 34 \\
\text { years) exposure in marine atmosphere. }\end{array}$ & {$[83,85]$} \\
\hline AWS & 19 years & $\begin{array}{l}\text { Atmospheric and } \\
\text { immersion }\end{array}$ & $\mathrm{Zn}, \mathrm{Al}$ & $80-460 \mu \mathrm{m}$ & Wire flame spraying & $\begin{array}{l}\text { Wash primer, } \\
\text { clear vinyl, } \\
\text { Al-pigmented vinyl, } \\
\text { Chlorinated rubber }\end{array}$ & No & $\begin{array}{l}\text { 80-150 um TSA coatings with and without } \\
\text { sealing protect steel in seawater and in } \\
\text { atmosphere. } \\
\text { The coating that gave the best } \\
\text { performance was a thin TSA. It exhibited } \\
\text { the lowest level of pitting and blistering. }\end{array}$ & [27] \\
\hline JACC & 18 years & $\begin{array}{l}\text { Atmospheric, } \\
\text { immersion }\end{array}$ & $\begin{array}{l}\mathrm{Zn}, \mathrm{Al}, \\
\mathrm{Zn}-\mathrm{Al}\end{array}$ & $\begin{array}{l}175 \pm 25 \mu \mathrm{m} \text { (flame and } \\
\text { arc-sprayed coating) } \\
400 \pm 25 \mu \mathrm{m} \text { only for Al } \\
\text { (arc-sprayed) }\end{array}$ & $\begin{array}{l}\text { Wire flame and } \\
\text { electric arc spraying }\end{array}$ & Epoxy & No & $\begin{array}{l}\text { TSA not effective in splash zone when } \\
\text { there is a damage in the coating. }\end{array}$ & [83] \\
\hline $\begin{array}{c}\text { PATINA } \\
\text { project }\end{array}$ & 3.5 years & Atmospheric & $\mathrm{Al}, \mathrm{Zn}, \mathrm{Zn}-\mathrm{Al}$ & $150 \mu \mathrm{m}$ & $\begin{array}{c}\text { Flame spraying } \\
\text { (type not specified) }\end{array}$ & No & Yes & $\begin{array}{l}\text { TSA only effective in atmosphere with } \\
\text { high chloride content. }\end{array}$ & [79] \\
\hline $\begin{array}{l}\text { the Corrosion } \\
\text { Advice } \\
\text { Bureau of } \\
\text { BISRA }\end{array}$ & 10 years & $\begin{array}{l}\text { Atmospheric, } \\
\text { immersion }\end{array}$ & $\begin{array}{c}\mathrm{Al}, \mathrm{Zn}, \\
\mathrm{Zn} \text { and } \mathrm{Al}\end{array}$ & $50,100,150 \mu \mathrm{m}$ & $\begin{array}{l}\text { Wire and powder } \\
\text { spraying } \\
\text { (exact method not } \\
\text { specified) }\end{array}$ & $\begin{array}{l}\text { Variety of paints } \\
\text { and topcoats }\end{array}$ & Yes & $\begin{array}{l}\text { Painted TSA can provide } 10 \text { years life } \\
\text { without maintenance under atmospheric } \\
\text { exposures. When damaged, rusting of the } \\
\text { substrate occurs under all conditions. } \\
\text { Unpainted Zn coatings failed under } \\
\text { immersion conditions, whereas unpainted } \\
\text { Al coatings provided protection. }\end{array}$ & [86] \\
\hline $\begin{array}{l}\text { US Army, } \\
\text { Buzzard's Bay }\end{array}$ & 20 years & $\begin{array}{c}\text { Atmospheric, } \\
\text { splash, tidal, } \\
\text { immersion } \\
\text { in natural seawater }\end{array}$ & $\begin{array}{l}\text { Various organic and } \\
\text { metallic coatings }\end{array}$ & $\begin{array}{l}150 \mu \mathrm{m} \text { (TSA without } \\
\text { sealant) } \\
80-90 \mu \mathrm{m} \text { sealed }\end{array}$ & Wire flame spraying & $\begin{array}{l}\text { Wash coati primer } \\
\text { and Al vinyl }\end{array}$ & Yes & $\begin{array}{l}\text { TSA with sealant was the best performing } \\
\text { coating among } 24 \text { systems tested } \\
\text { Unsealed Al coating failed in atmospheric } \\
\text { and splash zones (red rust present). }\end{array}$ & {$[62,87]$} \\
\hline $\begin{array}{l}\text { US Army, } \\
\text { La Costa } \\
\text { Island }\end{array}$ & $\begin{array}{l}21 \text { years, } \\
\text { results } \\
\text { reported after } \\
10 \text { years }\end{array}$ & $\begin{array}{l}\text { Atmospheric, } \\
\text { splash, tidal, } \\
\text { immersion } \\
\text { in natural seawater }\end{array}$ & $\begin{array}{l}\text { Various organic and } \\
\text { metallic coatings }\end{array}$ & $150 \mu \mathrm{m}$ & Wire flame spraying & Vinyl topcoat & Yes & $\begin{array}{l}\text { The most severe corrosion in the splash } \\
\text { zone. }\end{array}$ & {$[87,88]$} \\
\hline
\end{tabular}




\section{Laboratory Corrosion Testing Methods}

In order to predict the long-term performance of anti-corrosive coatings, long-term field testing is the most reliable approach; however, these are expensive and require long-term access to marine test sites. Short laboratory testing can give some indication and insight into the mechanisms that dictate the protectiveness of the system. The most common lab-based testing methods involve salt spray tests and electrochemical measurements, such as monitoring of the open circuit potential (OCP) and electrochemical impedance spectroscopy (EIS), during immersion tests. In order to estimate the rate of corrosion of the coatings, several methods have been employed by different researchers, such as linear polarisation resistance (LPR), polarisation curves, and mass change, as shown in Table 2.

Unfortunately, all of the above methods have some limitations. For example, the LPR method is not applicable when a non-conductive sealant or paint is used. Moreover, this technique should be used when the system undergoes general corrosion, whereas $\mathrm{Al}$ is known to suffer from localised corrosion in aqueous solutions containing $\mathrm{Cl}^{-}$ions.

Additionally, it should be mentioned that if the samples contain defects, the use of polarisation curves is not accurate, because anodic and cathodic polarization curves reflect reactions that occur on both metals simultaneously. Therefore, the Tafel slopes (which are needed to calculate corrosion rates) that are obtained from those curves are not accurate.

EIS is a powerful technique that is especially useful for studying coatings. However, the selection of appropriate equivalent electrical circuit that explains the mechanism occurring in the system can be very difficult, especially in case of porous coatings, such as TSA. Nonetheless, some researchers have done EIS modelling to understand the corrosion behaviour of sacrificial coatings [8,23,31,37,89-91].

The common industrial practices of the monitoring of corrosion based on salt spray testing and visual examination has its limitations, particularly for long-term prediction of performance. It is common laboratory practice to use $5 \mathrm{wt} \%$ or $3.5 \mathrm{wt} \% \mathrm{NaCl}$ solutions for salt spray tests, even though natural seawater contains other ions, such as $\mathrm{Mg}^{2+}, \mathrm{Ca}^{2+}$, and $\mathrm{SO}_{4}{ }^{2-}$, which play important roles in corrosion processes.

The estimation of corrosion rates based on the mass change of the samples is not applicable to thermally-sprayed coatings due to their porous nature. Corrosion products form on the coating, fill the pores, and are not possible to remove. Therefore, the mass of the corroded samples is changed due to both the dissolution of the coating and the corrosion products that get trapped inside it.

\section{In-Service Performance of Al Coatings}

One of the earliest applications of TSA coatings for the corrosion protection of an offshore structure was the Hutton tension leg platform (TLP) which was installed in 1984 in the North Sea [92]. TSA was applied on risers and tethers and flare boom. The risers were connected to the TLP hull (protected by an impressed current CP) and a subsea template (connected to sacrificial anodes). In 1986, one of the tethers was removed for inspection, and one of the risers was removed in the following year. The inspections revealed the presence of blisters on the coating that was applied on tethers (with vinyl sealer), and no signs of the degradation of the coating were observed on the risers (with silicone sealer). Apart from the blisters, TSA was in very good condition even after 12 years in service [26]. The possible reasons for the development of the blisters were related to the vinyl sealer, which either reacted with TSA or did not penetrate the coating.

In the Norwegian offshore sectors, TSA (mainly $\mathrm{Al}-5 \% \mathrm{Mg}$ ) has been used for the protection of several offshore structures (e.g., Shell Draugen field, Sleipner riser platform, Troll Gas, Heidrun field, Heimdal platform). By 1997, approximately $400,000 \mathrm{~m}^{2}$ of steel was protected by using TSA coatings. The most common areas that were protected by the TSA coatings include flare booms, crane booms, pipes, under cellar decks, vessels under thermal insulation, and burner booms [93]. An excellent performance of TSA with aluminium silicone paint on the Heimdal platform was reported after 10 years in service. However, a premature degradation of TSA was observed on the Sleipner platform (after seven years in service) as well as on Jotun B. In both cases, TSA coatings were applied as duplex 
systems consisting of sprayed aluminium and a thick overcoat [94]. A similar problem occurred on a gas platform near East Timor in Australia, where TSA failed after one year in service [95].

Another example where TSA did not provide adequate protection was the Heindrun TLP installed in 1995 in the Norwegian North Sea. After less than four years in service, a serious damage of the TSA coating (supported by CP from sacrificial anodes) with silicone sealer was observed on two oil export risers and one gas export riser operating in the splash zone. Further lab-based studies that were conducted to identify possible reasons for the TSA failure on the Heindrun risers revealed that the tendency of blistering increases with increases of coating thickness and the rise of pipe temperature. It was also observed that blistering can be mitigated by using a silicone sealer [26].

A very good performance of sealed TSA coatings that were applied on risers connected to sacrificial anodes was reported on the Jolliet tension leg platform operating in the Gulf of Mexico for 13 years [26].

TSA with organic topcoats was also used for the protection of bridges, such as Nidelv bridge in Trondheim, where the duplex system provided protection to the bridge for 30 years. However, when applied to Tromsø bridge, duplex coating failed after a year or less [93]. Some of the suggested possible factors that might have promoted the development of many blisters in the splash zone region included the insufficient quality of blast-cleaning and insufficient coating thickness [96].

Recently, TSA has been tested for the protection of offshore wind turbines as a part of the Cost Reduction for Offshore Wind Now (Crown) project [97]. TSA with epoxy paint as a sealant is also being used for the protection of offshore wind turbines operating in the Baltic Sea as a part of the Arkona project [98].

\section{Summary and Future Outlook}

The literature review revealed that TSA has proven its capability to successfully protect steel from corrosion in harsh marine environments when applied properly. The main conclusions that can be drawn from the substantial amount of work that has been devoted to understanding mechanisms and parameters controlling the performance of TSA are as follows:

1. It appears that the most economical spraying technique that is capable of producing coatings with low level of porosity and good adhesion is the electric arc spraying method.

2. Coating thickness is an important parameter that influences performance. The optimal thickness has been reported to be between 150-375 $\mu \mathrm{m}$. A lower thickness can result in an insufficient amount of aluminium to provide long-term protection to the substrate. An excessive coating thickness may lead to high residual coating stress leading to its premature failure.

3. The application of sealants can prolong the lifetime of the coating. Moreover, it has been suggested that sealing can prevent blistering. However, a low viscosity sealant that flows easily inside the pores without staying on top of the TSA should be used. The application of a thick organic layer on TSA may lead to an accelerated dissolution of the coating. The suggested failure mechanisms include the development of an acidic environment underneath the organic layer, the development of voluminous corrosion products rising the organic coating, anodic undermining, and cathodic disbondment.

4. It is important to differentiate between the self-corrosion of the coatings and how protective they are for steel when the coating is damaged or connected to bare steel. If large area of steel is exposed, the corrosion of TSA can be significantly higher due to the anodic nature of the coating.

5. Simulated laboratory tests should be conducted under intended service conditions. The testing of the coatings in $\mathrm{NaCl}$ solutions is not representative of in-service conditions and should be avoided. Seawater temperature and ions present in seawater play important roles in the corrosion of $\mathrm{Al}$ and the precipitation of calcareous deposits on cathodically polarised steel. Calcareous minerals are capable of impeding the diffusion of oxygen to the steel surface and reducing the dissolution rate of aluminium. Hence, constituents of these minerals such as $\mathrm{Ca}^{2+}$ and $\mathrm{Mg}^{2+}$ ions should be included in the test electrolyte. 
6. TSA has mostly been used in offshore structures with some form of CP system in place. Recently, TSA has been applied on offshore wind turbines as a stand-alone corrosion control method. However, no standards that cover the suitability of using TSA as a primary CP system exist.

Despite well-documented successful performance history of TSA, some gaps in knowledge still remain. Areas that have not been fully understood or addressed yet include:

- The determination of minimal salinity of water needed for the TSA to work effectively, especially if TSA contains defects.

- The performance of damaged TSA coatings in cold seawater, especially when not in conjunction with external CP.

- The suitability of using TSA coatings in splash zones.

- The suitability of using TSA coatings for the protection of high strength steels where hydrogen embrittlement is a concern.

Though cold-sprayed coatings have many advantages, such as low porosity and oxide levels, they have not been used for corrosion protection of steel structures in-service yet due to the higher costs (CAPEX AND OPEX) that are associated with cold spray systems. Only some limited laboratory data exist. To evaluate the corrosion performance of the coatings, long-term testing is needed.

Author Contributions: Conceptualization, B.S.-G.; writing-original draft preparation, B.S.-G.; writing-review A.J.D.; Review and editing-S.P.; supervision, A.J.D. and S.P. All authors have read and agreed to the published version of the manuscript.

Funding: This publication was made possible by the sponsorship and support of Lloyd's Register Foundation, a charitable foundation helping to protect life and property by supporting engineering-related education, public engagement and the application of research. The work was enabled through, and undertaken at, the National Structural Integrity Research Centre (NSIRC), a postgraduate engineering facility for industry-led research into structural integrity established and managed by TWI through a network of both national and international Universities. Authors gratefully acknowledge financial support from the Centre for Doctoral Training in Innovative Metal Processing (IMPaCT) funded by the UK Engineering and Physical Sciences Research Council (EPSRC), grant reference EP/L016206/1.

Acknowledgments: The authors would like to thank P. McNutt for the micrograph of cold-sprayed coating.

Conflicts of Interest: The authors declare no conflict of interest.

\section{References}

1. Koch, G.; Varney, J.; Thompson, N.; Moghissi, O.; Gould, M.; Payer, J. International measures of prevention, application, and economics of corrosion technologies study. NACE Int. 2016, 2-6.

2. López-Ortega, A.; Bayón, R.; Arana, J.L. Evaluation of protective coatings for high-corrosivity category atmospheres in offshore applications. Materials 2019, 12, 1325. [CrossRef]

3. Det Norske Veritas. Recommended Practice DNVGL-RP-0416 Corrosion Protection for Wind Turbines; DET NORSK VERITAS: Oslo, Norway, 2016.

4. Harb, S.V.; Trentin, A.; Torrico, R.F.O.; Pulcinelli, S.H.; Santilli, C.V.; Hammer, P. Organic-inorganic hybrid coatings for corrosion protection of metallic surfaces. In New Technologies in Protective Coatings; Giudice, C., Canosa, G., Eds.; IntechOpen: London, UK, 2017; pp. 19-52. [CrossRef]

5. Paul, S. Corrosion control for marine- and land-based infrastructure applications. In ASM Handbook-Volume 5A: Thermal Spray Technology; Tucker, R.C., Ed.; ASM International: Materials Park, OH, USA, 2013; Volume 5, pp. 248-252.

6. Det Norske Veritas. Recommended Practice DNVGL-RP-B401 Cathodic Protection Design; DET NORSK VERITAS: Oslo, Norway, 2017.

7. Cunningham, T.; Avery, R. Sealer coatings for thermal-sprayed aluminum in the offshore industry. Mater. Perform. 2000, 39, 46-48.

8. Zhu, Q.J.; Wang, K.; Wang, X.H.; Hou, B.R. Electrochemical impedance spectroscopy analysis of cold sprayed and arc sprayed aluminium coatings serviced in marine environment. Surf. Eng. 2012, 28, 300-305. [CrossRef] 
9. Malek, M.H.A.; Saad, N.H.; Abas, S.K.; Shah, N.M. Thermal arc spray overview. IOP Conf. Ser. Mater. Sci. Eng. 2013, 46, 012028. [CrossRef]

10. Fournier, J.; Miousse, D.; Legoux, J.-G. Wire-arc sprayed nickel based coatings for hydrogen evolution reaction in alkaline solutions. Int. J. Hydrog. Energy 1995, 24, 519-528. [CrossRef]

11. Tejero-Martin, D.; Rezvani Rad, M.; McDonald, A.; Hussain, T. Beyond traditional coatings: A review on thermal-sprayed functional and smart coatings. J. Therm. Spray Technol. 2019, 28, 598-644. [CrossRef]

12. Amin, S.; Panchal, H. A review on thermal spray coating processes. Int. J. Curr. Trends Eng. Res. 2016, 2, 556-563.

13. Davis, J.R. Introduction to thermal spray processing. In Handbook of Thermal Spray Technology; ASM International: Materials Park, OH, USA, 2004.

14. Sabard, A.; Hussain, T. Bonding mechanisms in cold spray deposition of gas atomised and solution heat-treated Al 6061 powder by EBSD. arXiv 2018, arXiv:1811.08694.

15. Champagne, V.; Helfritch, D. Critical assessment 11: Structural repairs by cold spray. Mater. Sci. Technol. 2015, 31, 627-634. [CrossRef]

16. Champagne, V.K. (Ed.) The Cold Spray Materials Deposition Process: Fundamentals and Applications; Woodhead Publishing Limited: Cambridge, UK, 2007; ISBN 9781845691813.

17. Pathak, S.; Saha, G.C. Development of sustainable cold spray coatings and 3D additive manufacturing components for repair/manufacturing applications: A critical review. Coatings 2017, 7, 122. [CrossRef]

18. Pombo, R.R.M.H.; Paredes, R.S.C.; Wido, S.H.; Calixto, A. Comparison of aluminum coatings deposited by flame spray and by electric arc spray. Surf. Coat. Technol. 2007, 202, 172-179.

19. Gartland, P.O.; Eggen, T.G. Cathodic and anodic properties of thermally sprayed Al and Zn-based coatings in seawater Paper No. 367. In Proceedings of the Corrosion 90; NACE International: Houston, TX, USA, 1990.

20. Bardal, E. The effect of surface preparation on the adhesion of arc and flame-sprayed aluminum and zinc coatings to mild steel. In Proceedings of the 7th International Metal Spraying Conference, London, UK, 10-14 September 1973.

21. Lieberman, E.S.; Clayton, C.R.; Herman, H. Thermally Sprayed Active Metal Coatings for Corrosion Protection in Marine Environments; Report; Defense Technical Information Center: Fort Belvoir, VA, USA, 1984.

22. American Welding Society Guide for the Protection of Steel with Thermal Sprayed Coatings of Aluminium and Zinc and their Alloys and Composites; AWS C2.18: Florida, FL, USA, 1993.

23. Li, N.; Li, W.Y.; Yang, X.W.; Alexopoulos, N.D.; Niu, P.L. Effect of powder size on the long-term corrosion performance of pure aluminium coatings on mild steel by cold spraying. Mater. Corros. 2017, 68, 546-551. [CrossRef]

24. Han, M.S.; Woo, Y.B.; Ko, S.C.; Jeong, Y.J.; Jang, S.K.; Kim, S.J. Effects of thickness of Al thermal spray coating for STS 304. Trans. Nonferrous Met. Soc. China (Engl. Ed.) 2009, 19, 925-929. [CrossRef]

25. Malek, M.H.A.; Saad, N.H.; Abas, S.K.; Roselina, N.R.N.; Shah, N.M. Performance and microstructure analysis of $99.5 \%$ aluminium coating by thermal arc spray technique. Procedia Eng. 2013, 68, 558-565. [CrossRef]

26. Thomason, W.H.; Olsen, S.; Haugen, T.; Fischer, K. Deterioration of thermal sprayed aluminum coatings on hot risers due to thermal cycling Paper No. 04021. In Proceedings of the Corrosion 2004, New Orleans, LA, USA, 28 March-1 April 2004; NACE International: New Orleans, LA, USA, 2004.

27. American Welding Society. Corrosion Testing of Flame-Sprayed Coated Steel-19 Year Report C2.14-74, 1974.

28. Paul, S.; Lee, C.M.; Harvey, M.D.F. Improved coatings for extended design life of $22 \%$ Cr duplex stainless steel in marine environments. In Proceedings of the Thermal Spray 2012: Proceedings from the International Thermal Spray Conference and Exposition; ASM International: Houston, TX, USA, 2012; pp. 544-549.

29. Paul, S.; Harvey, M.D.F.; Ho, Q.Y.; Yunus, K.; Fisher, A.C. Corrosion testing of thermally sprayed aluminum. In Proceedings of the Thermal Spray 2015: Proceedings from the International Thermal Spray Conference; ASM International: Long Beach, CA, USA, 2015; pp. 964-970.

30. Quale, G.; Årtun, L.; Iannuzzi, M.; Johnsen, R. Cathodic protection by distributed sacrificial anodes-A new cost- effective solution to prevent corrosion of subsea structures Paper No. 8941. In Proceedings of the Corrosion 2017; NACE International: New Orleans, LA, USA, 2017.

31. Abedi Esfahani, E.; Salimijazi, H.; Golozar, M.A.; Mostaghimi, J.; Pershin, L. Study of corrosion behaviour of Arc sprayed aluminum coating on mild steel. J. Therm. Spray Technol. 2012, 21, 1195-1202. [CrossRef] 
32. Wilson, H.; Johnsen, R.; Rodriguez, C.T.; Hesjevik, S.M. Properties of TSA in natural seawater at ambient and elevated temperature. Mater. Corros. 2019, 7, 293-306. [CrossRef]

33. Knudsen, O.Ø.; Van Bokhorst, J.; Clapp, G.; Duncan, G. Technical note: Corrosion of cathodically polarized thermally sprayed aluminum in subsea mud at high temperature. Corrosion 2016, 72, 560-568.

34. Syrek-Gerstenkorn, B.; Paul, S.; Davenport, A.J. Use of thermally sprayed aluminium (TSA) coatings to protect offshore structures in submerged and splash zones. Surf. Coat. Technol. 2019, 374, 124-133. [CrossRef]

35. Echaniz, R.G.; Paul, S.; Thornton, R. Effect of seawater constituents on the performance of thermal spray aluminum in marine environments. Mater. Corros. 2019, 70, 996-1004. [CrossRef]

36. Lee, H.S.; Singh, J.K.; Park, J.H. Pore blocking characteristics of corrosion products formed on Aluminium coating produced by arc thermal metal spray process in $3.5 \mathrm{wt} . \% \mathrm{NaCl}$ solution. Constr. Build. Mater. 2016, 113, 905-916. [CrossRef]

37. Abdoli, L.; Huang, J.; Li, H. Electrochemical corrosion behaviors of aluminum-based marine coatings in the presence of Escherichia coli bacterial biofilm. Mater. Chem. Phys. 2016, 173, 62-69. [CrossRef]

38. Bai, X.; Tang, J.; Gong, J.; Lü, X. Corrosion performance of $\mathrm{Al}_{-}-\mathrm{Al}_{2} \mathrm{O}_{3}$ cold sprayed coatings on mild carbon steel pipe under thermal insulation. Chin. J. Chem. Eng. 2017, 25, 533-539. [CrossRef]

39. Paul, S. Corrosion performance of damaged thermally sprayed aluminiun in synthetic seawater at different temperatures. Therm. Spray Bull. 2015, 67, 139-146.

40. Yung, T.Y.; Chen, T.C.; Tsai, K.C.; Lu, W.F.; Huang, J.Y.; Liu, T.Y. Thermal spray coatings of Al, ZnAl and Inconel 625 alloys on SS304L for anti-saline corrosion. Coatings 2019, 9, 32. [CrossRef]

41. Ghali, E. Corrosion Resistance of Aluminium and Magnesium Alloys: Understadning, Performance and Testing; John Wiley \& Sons: Hoboken, NJ, USA, 2010.

42. Yan, J.; Heckman, N.M.; Velasco, L.; Hodge, A.M. Improve sensitization and corrosion resistance of an Al-Mg alloy by optimization of grain boundaries. Sci. Rep. 2016, 6, 1-10. [CrossRef] [PubMed]

43. Morakul, S.; Otsuka, Y.; Miyashita, Y.; Mutoh, Y. Effect of Mg concentration on interfacial strength and corrosion fatigue behaviour of thermal-sprayed Al-Mg coating layers. Eng. Fail. Anal. 2018, 88, 13-24. [CrossRef]

44. Adamiak, M.; Czupr Nski, A.; Kopy, A.; Monica, Z.; Olender, M.; Gwiazda, A. The properties of arc-sprayed aluminum coatings on armor-grade steel. Metals 2018, 8, 142. [CrossRef]

45. Irissou, E.; Legoux, J.G.; Arsenault, B.; Moreau, C. Investigation of $\mathrm{Al}^{-} \mathrm{Al}_{2} \mathrm{O}_{3}$ cold spray coating formation and properties. J. Therm. Spray Technol. 2007, 16, 661-668. [CrossRef]

46. Silva, F.S.D.; Bedoya, J.; Dosta, S.; Cinca, N.; Cano, I.G.; Guilemany, J.M.; Benedetti, A.V. Corrosion characteristics of cold gas spray coatings of reinforced aluminum deposited onto carbon steel. Corros. Sci. 2017, 114, 57-71. [CrossRef]

47. Huang, J.; Liu, Y.; Yuan, J.; Li, H. Al/ $\mathrm{Al}_{2} \mathrm{O}_{3}$ composite coating deposited by flame spraying for marine applications: Alumina skeleton enhances anti-corrosion and wear performances. J. Therm. Spray Technol. 2014, 23, 676-683. [CrossRef]

48. Fauchais, P.; Vardelle, A. Thermal sprayed coatings used against corrosion and corrosive wear. In Advanced Spray Applications; Jazi, H.S., Ed.; IntechOpen: London, UK, 2012; pp. 3-39. ISBN 978-953-51-0349-3.

49. NORSOK Standard M-501 Surface Preparation and Protective Coating, 2004.

50. López-Ortega, A.; Bayón, R.; Arana, J.L. Evaluation of protective coatings for offshore applications. Corrosion and tribocorrosion behaviour in synthetic seawater. Surf. Coat. Technol. 2018, 349, 1083-1097. [CrossRef]

51. López-Ortega, A.; Areitioaurtena, O.; Alves, S.A.; Goitandia, A.M.; Elexpe, I.; Arana, J.L.; Bayón, R. Development of a superhydrophobic and bactericide organic topcoat to be applied on thermally sprayed aluminum coatings in offshore submerged components. Prog. Org. Coat. 2019, 137, 105376. [CrossRef]

52. Gu, W.; Shen, D.; Wang, Y.; Chen, G.; Feng, W.; Zhang, G.; Fan, S.; Liu, C.; Yang, S. Deposition of duplex $\mathrm{Al} 2 \mathrm{O} 3$ /aluminum coatings on steel using a combined technique of arc spraying and plasma electrolytic oxidation. Appl. Surf. Sci. 2006, 252, 2927-2932. [CrossRef]

53. López-Ortega, A.; Arana, J.L.; Rodríguez, E.; Bayón, R. Corrosion, wear and tribocorrosion performance of a thermally sprayed aluminum coating modified by plasma electrolytic oxidation technique for offshore submerged components protection. Corros. Sci. 2018, 143, 258-280. [CrossRef]

54. Pang, X.; Wang, R.; Wei, Q.; Zhou, J. Effect of epoxy resin sealing on corrosion resistance of arc spraying aluminium coating using cathode electrophoresis method. Mater. Res. Express 2018, 5, 016527. [CrossRef] 
55. Wang, Y.; Zhang, T.; Zhao, W.; Tang, X. Sealing Treatment of Aluminium Coating on S235 Steel with Thermal Diffusion of Zinc. J. Therm. Spray Technol. 2015, 24, 1052-1059. [CrossRef]

56. Lee, H.-S.; Singh, J.K.; Ismail, M.A. An effective and novel pore sealing agent to enhance the corrosion resistance performance of Al coating in artificial ocean water. Sci. Rep. 2017, 7, 41935. [CrossRef] [PubMed]

57. Lee, H.; Kumar, A.; Mandal, S.; Singh, J.K.; Aslam, F.; Alyousef, R.; Albduljabbar, H. Effect of sodium phosphate and calcium nitrate sealing treatment on microstructure and corrosion resistance of wire arc sprayed aluminum coatings. Coatings 2020, 10, 33. [CrossRef]

58. Liu, L.M.; Wang, Z.; Song, G. Study on corrosion resistance properties of hydrothermal sealed arc sprayed aluminium coating. Surf. Eng. 2010, 26, 399-406. [CrossRef]

59. Armada, S.; Tilset, B.G.; Pilz, M.; Liltvedt, R.; Bratland, H.; Espallargas, N. Sealing HVOF thermally sprayed WC-CoCr coatings by sol-gel methods. J. Therm. Spray Technol. 2011, 20, 918-926. [CrossRef]

60. Wang, R.; Zhou, J. Effect of glass powder sealings on the corrosion resistance of arc sprayed Al coating. Mater. Res. Express 2019, 6, 086566. [CrossRef]

61. Wenming, L.; Tianyuan, S.; Dejun, K. Effects of laser remelting on surface-interface morphologies, bonding modes and corrosion performances of arc-sprayed Al coating. Anti Corros. Methods Mater. 2017, 64, 43-51. [CrossRef]

62. Fischer, K.P.; Thomason, W.H.; Rosbrook, T.; Murali, J. Performance history of thermal-sprayed aluminum coatings in offshore service. Mater. Perform. 1995, 34, 27-35.

63. Knudsen, O.Ø.; Rogne, T.; Røssland, T. Rapid degradation of painted TSA Paper No. 04023. In Proceedings of the Corrosion 2004; NACE International: New Orleans, LA, USA, 2004.

64. Sumon, T.A.; Lyon, S.B.; Scantlebury, J.D. Failure of aluminium metal spray/organic duplex coating systems on structural steel. Corros. Eng. Sci. Technol. 2013, 48, 552-557. [CrossRef]

65. Thomason, W.H. Offshore corrosion protection with thermal-sprayed aluminum. In Proceedings of the Offshore Technology Conference, Houston, TX, USA, 6-9 May 1985.

66. Huang, G.; Lou, X.; Wang, H.; Li, X.; Xing, L. Investigation on the cathodic protection effect of low pressure cold sprayed AlZn coating in seawater via numerical simulation. Coatings 2017, 7, 93. [CrossRef]

67. Ce, N.; Paul, S. Thermally Sprayed Aluminium Coatings for the Protection of Subsea Risers and Pipelines Carrying Hot Fluids. Coatings 2016, 6, 58. [CrossRef]

68. Ce, N.; Paul, S. The effect of temperature and local $\mathrm{pH}$ on calcareous deposit formation in damaged thermal spray aluminum (TSA) coatings and its implication on corrosion mitigation of offshore steel structures. Coatings 2017, 7, 52. [CrossRef]

69. Lin, S.-H.; Dexter, S.C. Effects of temperature and magnesium ions on calcareous deposition. Corrosion 1988, 44, 615-622. [CrossRef]

70. Yang, Y.; Scantlebury, J.D.; Koroleva, E.V. A Study of calcareous deposits on cathodically protected mild steel in artificial seawater. Metals 2015, 5, 439-456. [CrossRef]

71. Knudsen, O.Ø.; Van Bokhorst, J.; Clapp, G.; Duncan, G. Corrosion of cathodically polarized TSA in subsea mud at high temperature Paper No. 4196. In Proceedings of the Corrosion 2004, San Antonio, TX, USA, 9-13 March 2014; NACE International: San Antonio, TX, USA, 2014.

72. Paul, S. Protection of deep sea steel structures using thermally sprayed aluminium Paper No. 9009. In Proceedings of the Corrosion 2017, New Orleans, LA, USA, 26-30 March 2017; NACE International: New Orleans, LA, USA, 2017.

73. Dexter, S.C. Effect of variations in sea water upon the corrosion of aluminum. Corrosion 1980, 36, $423-432$. [CrossRef]

74. Paul, S. Behavior of damaged thermally sprayed aluminum (TSA) in aerated and dearated seawater Paper No. 12766. In Proceedings of the Corrosion 2019, Nashville, TN, USA, 24-28 March 2019; NACE International: Nashville, TN, USA, 2019.

75. Pryor, M.J.; Keir, D.S. Galvanic corrosion: I. current flow and polarization characteristics of the aluminium-steel and zinc-steel couples in sodium chloride solution. J. Electrochem. Soc. 1957, 104, 269-275. [CrossRef]

76. Frankel, G.S. Pitting corrosion of metals. A review of the critical factors. J. Electrochem. Soc. 1998, 145, 2186-2198. [CrossRef]

77. Szklarska-Smialowska, Z. Pitting corrosion of aluminum. Corros. Sci. 1998, 41, 1743-1767. [CrossRef]

78. Natishan, P.M.; O'Grady, W.E. Chloride ion interactions with oxide-covered aluminum leading to pitting corrosion: A review. J. Electrochem. Soc. 2014, 161, C421-C432. [CrossRef] 
79. Panossian, Z.; Mariaca, L.; Morcillo, M.; Flores, S.; Rocha, J.; Peña, J.J.; Herrera, F.; Corvo, F.; Sanchez, M.; Rincon, O.T.; et al. Steel cathodic protection afforded by zinc, aluminium and zinc/aluminium alloy coatings in the atmosphere. Surf. Coat. Technol. 2005, 190, 244-248. [CrossRef]

80. Rios, G. Effect of chlorides on the electrochemical behaviour of thermally sprayed aluminium protective coatings. Ph.D. Thesis, University of Manchester, Manchester, UK, 2012.

81. Na, K.H.; Pyun, S. Il Effects of SO42-, S2O 32- and HSO4- Ion additives on the pitting corrosion of pure aluminium in $1 \mathrm{M} \mathrm{NaCl}$ solution at $40-70^{\circ} \mathrm{C}$. J. Solid State Electrochem. 2005, 9, 639-645. [CrossRef]

82. Wu, T.I.; Wu, J.K. Effect of sulfate ions on corrosion inhibition of AA 7075 aluminum alloy in sodium chloride solutions. Corrosion 1995, 51, 185-190. [CrossRef]

83. Kuroda, S.; Kawakita, J.; Takemoto, M. An 18-year exposure test of thermal-sprayed Zn, Al, and Zn-Al coatings in marine environment. Corrosion 2006, 62, 635-647. [CrossRef]

84. Mansford, R.E. Sprayed aluminium and zinc in corrosive environments. Corros. Technol. 1956, $314-316$. [CrossRef]

85. Hoar, T.P.; Radovici, O. Zinc-aluminium sprayed coatings. Trans. IMF 1964, 42, 211-222. [CrossRef]

86. Watkins, K.O. Painting of metal-sprayed structural steelwork: Report on the condition of specimens after 10 years' exposure. Br. Corros. J. 1974, 9, 204-210. [CrossRef]

87. Kumar, A.; Van Blaricum, V.; Beitelman, A.; Boy, J. Twenty year field study of the performance of coatings in seawater. In Corrosion Testing in Natural Waters; Young, W., Kain, R., Eds.; ASTM International: West Conshohocken, PA, USA, 1997; Volume Second, pp. 74-90.

88. Bukowski, J.; Kumar, A. Coatings and Cathodic Protection of Piling on Seawater: Results of 10-Year Exposure at LaCosta Island, Fl; Tech. Rep. M-321; Constr. Eng. Lab, US Army: Champaign, IL, USA, 1982.

89. Jiang, Q.; Miao, Q.; Liang, W.; Ying, F.; Tong, F.; Xu, Y.; Ren, B.; Yao, Z.; Zhang, P. Corrosion behaviour of arc sprayed Al-Zn-Si-RE coatings on mild steel in 3.5wt\% NaCl solution. Electrochim. Acta 2013, 115, 644-656. [CrossRef]

90. Lee, H.S.; Kwon, S.J.; Singh, J.K.; Ismail, M.A. Influence of Zn and Mg alloying on the corrosion resistance properties of $\mathrm{Al}$ coating applied by arc thermal spray process in simulated weather solution. Acta Metall. Sin. (Engl. Lett.) 2018, 31, 591-603. [CrossRef]

91. Lee, H.S.; Singh, J.K.; Ismail, M.A.; Bhattacharya, C.; Seikh, A.H.; Alharthi, N.; Hussain, R.R. Corrosion mechanism and kinetics of Al-Zn coating deposited by arc thermal spraying process in saline solution at prolong exposure periods. Sci. Rep. 2019, 9, 1-17. [CrossRef]

92. Tiong, D.K.-K.; Pit, H. Experiences on "thermal spray aluminium (TSA)" coating on offshore structures Conference paper No. 04022. In Proceedings of the Corrosion 2004; NACE International: New Orleans, LA, USA, 2004.

93. Doble, O.; Pryde, G.; Oil, K. Use of thermally sprayed aluminium in the Norwegian Offshore Industry. Prot. Coat. Eur. 1997, 2, 1-10.

94. Knudsen, O.Ø. Coating Systems for LONG lifetime: Thermally Sprayed Duplex Systems SINTEF Report A14189; SINTEF: Trondheim, Norway, 2010.

95. Mandeno, W.L. Thermal metal spray: Successes, failures and lessons learned. In Proceedings of the Proceedings of Australasian Corrosion Association Corrosion \& Prevention Conference, Melbourne, Australia, 11-14 November 2012.

96. Klinge, R. Altered specifications for the protection of Norwegian steel bridges and offshore structures against corrosion. Steel Constr. 2009, 2, 109-118. [CrossRef]

97. TWI Ltd. CROWN Project Commended for Offshore Win Corrosion Work. Available online: https://www.twi-global.com/media-and-events/press-releases/2018-02-collaborative-crown-projectcommended-for-offshore-wind-corrosion-work (accessed on 7 January 2020).

98. Matthiesen, H. Arkona Offshore Wind Project. Available online: Ttps://www.norwep.com/content/download/ 32957/239720/version/1/file/Mathiesen+2017-12-04_Norwegian+Offshore+Delegation_Arkona+Offshore+ Wind+Project.pdf (accessed on 7 January 2020).

(C) 2020 by the authors. Licensee MDPI, Basel, Switzerland. This article is an open access article distributed under the terms and conditions of the Creative Commons Attribution (CC BY) license (http://creativecommons.org/licenses/by/4.0/). 